\title{
Dispersion of Smoke Plumes over South America
}

\author{
MARK R. JURY ${ }^{\mathrm{a}, \mathrm{b}}$ AND AMÉRICA R. GAVIRIA PABÓN ${ }^{\mathrm{a}}$ \\ ${ }^{\text {a }}$ Physics Department, University of Puerto Rico Mayagüez, Mayagüez, Puerto Rico \\ ${ }^{\mathrm{b}}$ Geography Department, University of Zululand, Richards Bay, South Africa
}

(Manuscript received 23 March 2020, in final form 19 December 2020)

\begin{abstract}
Satellite and reanalysis products are used to study the atmospheric environment, aerosols, and trace gases in smoke plumes over South America in the period 2000-18. Climatic conditions and fire density maps provide context to link biomass burning across the southern Amazon region $\left(5^{\circ}-15^{\circ} \mathrm{S}, 50^{\circ}-70^{\circ} \mathrm{W}\right)$ to thick near-surface plumes of trace gases and fine aerosols. Intraseasonal weather patterns that underpin greater fire emissions in the dry season (July-October) are exacerbated by high pressure over a cool eastern Pacific Ocean, for example in September 2007. Smoke-plume dispersion simulated with HYSPLIT reveals a slowing of westward transport between sources in eastern Brazil and the Andes Mountains. During cases of thick smoke plumes over southern Amazon, an upper ridge and sinking motions confine trace gases and fine aerosols below $4 \mathrm{~km}$. Long-term warming, which tends to coincide with the zone of biomass burning, is $+0.03^{\circ} \mathrm{C} \mathrm{yr}^{-1}$ in the air and $+0.1^{\circ} \mathrm{C} \mathrm{yr}^{-1}$ at the land surface. Our study suggests that weather conditions promoting fire emissions also tend to limit dispersion.
\end{abstract}

KEYWORDS: South America; Forest fires; Trace gases; Dispersion

\section{Introduction}

Greenhouse gases such as carbon dioxide are accumulating, and concentrations have more than doubled since the eighteenth century due to industrial and agricultural emissions (IPCC 2021). Over $1 \mathrm{Pg} \mathrm{yr}^{-1}$ of smoke is released into the atmosphere through biomass burning, of which about two-thirds is from the tropics (Andreae 2019). South America has almost 0.5 billion people and an agricultural sector contribution of $\$ 200$ billion involving forest-to-farm conversion (Artaxo et al. 2002, 2013; Thornhill et al. 2018) that generates smoke plumes filled with traces gases such as carbon monoxide (CO) with a residence time of less than 2 months. Biomass burning in the southern Amazon, as in southern Africa, increases during the dry season from July to October (Garreaud and Aceituno 2001; Kingtse and Berbery 2011; Jury 2019; Yang et al. 2018). The smoke plumes extend thousands of kilometers and diminish regional air quality, impacting human health and the environment (Butt et al. 2020). Techniques to monitor fire emissions have advanced since 2000 via satellite radiometers such as MODIS and Measurements of Pollution in the Troposphere (MOPITT) and data assimilation products such as MERRA-2; hence rural air constituents and dispersion pathways can be detected. Recent studies have determined that heat-trapping trace gas emissions from tropical biomass burning are $\sim 20$ times particulate emissions (Andreae 2019) and contribute to the melting of Andean glaciers (Magalhães et al. 2019). Procopio et al. (2004) determined that wet-season-to-dryseason changes in atmospheric composition from biomass

Corresponding author: Mark R. Jury, mark.jury@upr.edu

Earth Interactions is published jointly by the American Meteorological Society, the American Geophysical Union, and the Association of American Geographers. burning increased radiative heating from 3 to $30 \mathrm{~W} \mathrm{~m}^{-2}$ over the southern Amazon (an area of $2 \times 10^{6} \mathrm{~km}^{2}$ ), leading to an RCP8.5-projected $+5^{\circ} \mathrm{C}$ rise of air temperature over the twenty-first century (Magrin et al. 2014, their Fig. 27-2).

The loss of vegetation cover compounds atmospheric heating by altering the albedo. Following a decade of moderation, deforestation increased from $\sim 6000$ to $\sim 10000 \mathrm{~km}^{2} \mathrm{yr}^{-1}$ in 2019 (Pasquali 2020) as the Amazon is cleared for farming, logging and peri-urban infrastructure, thereby limiting transpiration and rainfall (Cochrane and Laurance 2008). Our work here will consider the atmospheric dispersion of smoke plumes from the southern Amazon (Penner et al. 1992; Ross et al. 1998; $\mathrm{Li}$ et al. 2000). We describe how seasonal weather conditions accelerate fire emissions and limit the dispersion of smoke plumes by stagnation of flow beneath a subsiding layer. In the concluding section we link the changing atmospheric composition to warming trends.

\section{Data and methods}

Our study covers an outer domain of $40^{\circ} \mathrm{S}-15^{\circ} \mathrm{N}, 30^{\circ}-90^{\circ} \mathrm{W}$ and a southern Amazon index area that covers $5^{\circ}-15^{\circ} \mathrm{S}, 50^{\circ}-$ $70^{\circ} \mathrm{W}, \sim 2.4 \times 10^{6} \mathrm{~km}^{2}$. This area (cf. Fig. 1d) has LaPaz/ Brasilia at the lower corners and Manaus near the top center, and it lies downwind (west) of fire emissions. Concentrations of near-surface trace gases: carbon monoxide (CO), methane $\left(\mathrm{CH}_{4}\right)$, ozone $\left(\mathrm{O}_{3}\right)$, nitrogen dioxide $\left(\mathrm{NO}_{2}\right)$, and fine particulates [aerosol optical depth (AOD)] were obtained from the MOPITT, AIRS, Ozone Monitoring Instrument (OMI), and MODIS satellite radiometers and from MERRA-2 reanalysis via NASA Giovanni (Acker and Leptoukh 2007). The MOPITT radiometer detects $2.3-4.7-\mu \mathrm{m}$ spectral bands sensitive to nearsurface CO (Worden et al. 2010), and monthly means were obtained (algorithm v8). Because of its wider swath, daily CO and $\mathrm{CH}_{4}$ data (algorithm v6) were obtained from the AIRS radiometer (Yurganov et al. 2008; Thonat et al. 2012). The AOD 

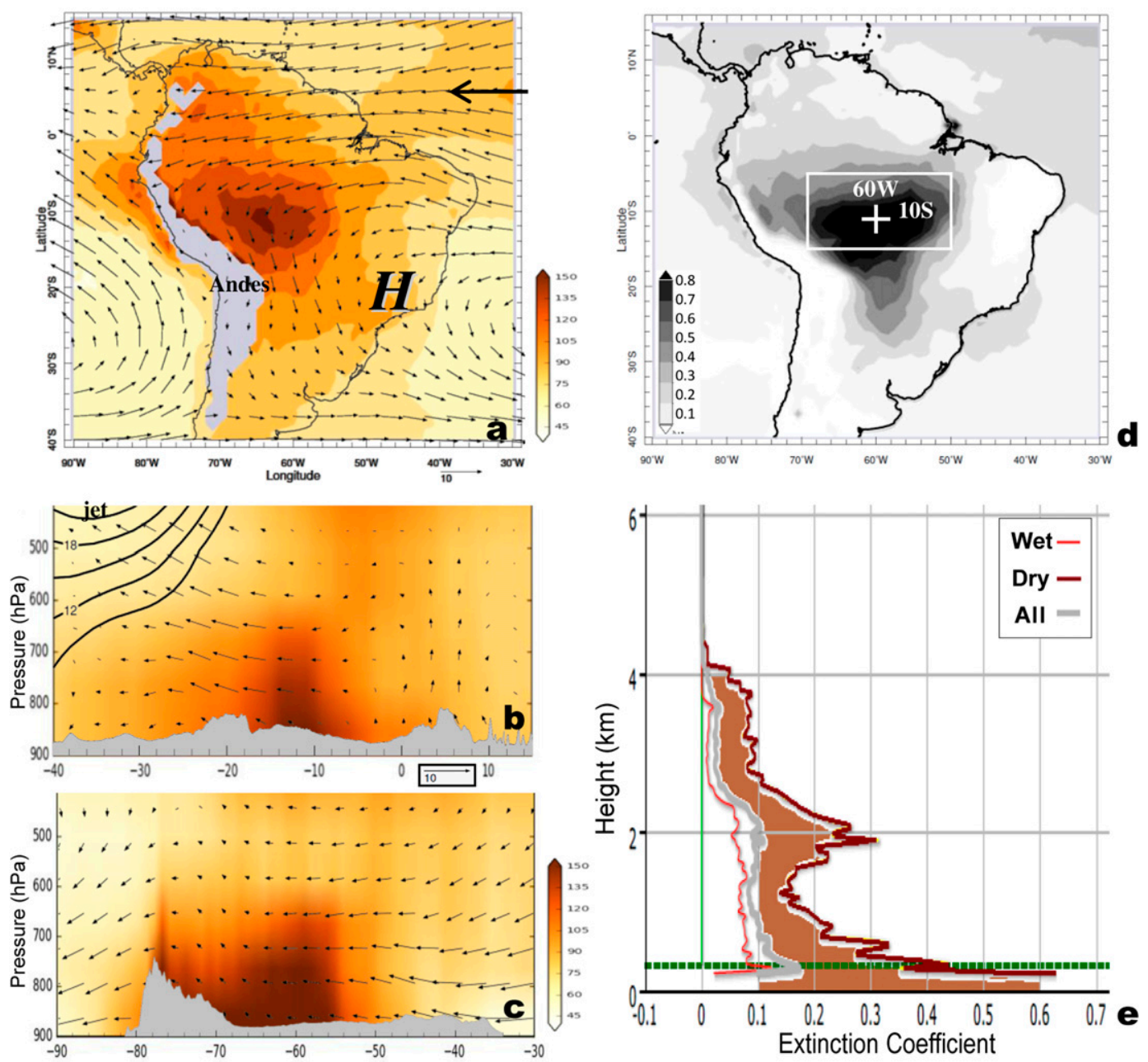

FIG. 1. Annual mean map of (a) MOPITT 900-hPa CO (shaded; ppb) and 925-700-hPa wind vectors (the large arrow refers to smoke plumes from Africa). Annual mean vertical sections of MOPITT CO (shaded; ppb) and atmospheric circulation: (b) south-north axis $\left(55^{\circ}-65^{\circ} \mathrm{W}\right)$ meridional vectors and upper jet contours and (c) west-east axis $\left(7^{\circ}-13^{\circ} \mathrm{S}\right)$ zonal vectors; vertical motion is exaggerated 50 -fold. (d) MODIS AOD $0.550 \mu \mathrm{m}$ and southern Amazon index (outlined box). (e) Seasonal aerosol profiles from CALIPSO $0.532-\mu \mathrm{m}$ extinction over the southern Amazon index area, with dry season shaded.

fraction was extracted at monthly and daily time scales from MODIS radiometer scattering at $0.55 \mu \mathrm{m}$ (algorithm v6). Tropospheric $\mathrm{NO}_{2}$ data were obtained from the OMI satellite radiometer (Bucsela et al. 2013). Table 1 lists the acronyms and details of the datasets. The methods are applied in sequence: (i) mean patterns of dispersion, (ii) characteristics of fire emissions, (iii) year-to-year and day-to-day variability, (iv) analysis of a period of high smoke emissions, and (v) climate trends. Among the air constituents, $\mathrm{CO}$ and AOD are more localized and best describe smoke-plume dispersion.

MERRA-2 is based on global data assimilation by NASA that provides gridded fields of atmospheric variables, aerosols, and trace gases, coupled with the land and ocean (Molod et al. 2015; Randles et al. 2017). A secondary atmospheric reanalysis used here is NCEP2 (Kanamitsu et al. 2002). The meteorological data include near-surface winds, surface air pressure, air temperature and humidity, and derived variables such as heat and moisture fluxes and vertical motion. Supplementary data include MODIS fire emission and count density (firms.modaps. eosdis.nasa.gov/; globalfiredata.org/) based on Justice et al. (2002), and CALIPSO satellite aerosol profiles based on lidar extinction at 0.532-1.064 $\mu \mathrm{m}$ (Winker et al. 2007; Amiridis et al. 2015).

Monthly CO time series were formed by averaging the 900hPa MOPITT and MERRA-2 values over the southern Amazon, $5^{\circ}-15^{\circ} \mathrm{S}, 50^{\circ}-70^{\circ} \mathrm{W}$, in the period $2000-18$, and then calculating the mean annual cycle. All-year and dry-season patterns were analyzed, and vertical sections of $\mathrm{CO}$ concentration and NCEP2 circulations were averaged over $55^{\circ}-65^{\circ} \mathrm{W}$ and $7^{\circ}-13^{\circ} \mathrm{S}$. To understand how variations in southern Amazon CO values each dry season (July-October) are forced, field correlations were calculated with NOAA sea surface 
TABLE 1. Dataset acronyms and details.

\begin{tabular}{|c|c|c|c|}
\hline Acronym & Name & Space resolution; time resolution & Quantity \\
\hline AIRS & Atmospheric Infrared Sounder, version 6 & $100 \mathrm{~km}$; daily and monthly & $\mathrm{CO}$ and $\mathrm{CH}_{4}$ near surface \\
\hline CALIPSO & $\begin{array}{l}\text { Cloud-Aerosol Lidar and Infrared } \\
\text { Pathfinder Satellite Observation, L3 }\end{array}$ & $\sim 10 \mathrm{~km}$ at zenith; weekly overpass & $\begin{array}{l}\text { Fine aerosol density, from light } \\
\text { extinction }\end{array}$ \\
\hline HYSPLIT & $\begin{array}{l}\text { Hybrid Single-Particle Lagrangian } \\
\text { Integrated Trajectory model }\end{array}$ & $\sim 10 \mathrm{~km}$; within plume & Forward dispersion simulation \\
\hline MERRA-2 & $\begin{array}{l}\text { Modern-Era Retrospective Analysis for } \\
\text { Research and Applications with } \\
\text { GEOS-5 air chemistry, version } 5\end{array}$ & $\sim 50 \mathrm{~km}$; 3-hourly, daily, and monthly & $\begin{array}{l}\text { Near-surface } \mathrm{O}_{3}, \mathrm{CO} \text {, and } \\
\quad \text { meteorological conditions }\end{array}$ \\
\hline NCEP2 & $\begin{array}{l}\text { National Centers for Environmental } \\
\text { Prediction, version 2, reanalysis }\end{array}$ & 180 km; monthly & Atmospheric circulation \\
\hline MODIS & $\begin{array}{l}\text { Moderate Resolution Imaging } \\
\text { Spectrometer, version 8, visible and } \\
\text { infrared emissions/backscatter }\end{array}$ & $\sim 10 \mathrm{~km}$; daily and monthly & Imagery, fires, and AOD \\
\hline MOPITT & $\begin{array}{l}\text { Measurements of Pollution in the } \\
\text { Troposphere, version } 8\end{array}$ & $100 \mathrm{~km}$; monthly & $\mathrm{CO}$, near surface, and multispectral \\
\hline NOAA & $\begin{array}{l}\text { National Oceanic and Atmospheric } \\
\text { Administration satellite visible and } \\
\text { infrared composites }\end{array}$ & $10-100 \mathrm{~km}$; daily and monthly & Vegetation, SST, and net OLR \\
\hline OMI & $\begin{array}{l}\text { Ozone Monitoring Instrument (Aura } \\
\text { satellite) v3 }\end{array}$ & $25 \mathrm{~km}$; twice daily & Near-surface $\mathrm{NO}_{2}$ \\
\hline
\end{tabular}

temperature and vegetation fraction, and MERRA-2 sea level air pressure, $500-\mathrm{hPa}$ zonal winds, and soil moisture, where $90 \%$ confidence is reached with correlation coefficient $r>$ $|0.35|$ for a sample size of 18 years. Similarly, temporal lag correlations of July-October CO values (peaks in Fig. 3a) with Niño-3 Pacific SST and southern Amazon soil moisture and satellite vegetation were calculated from -12 to +12 months to understand what is driving the interannual variability.

Daily satellite concentrations of smoke-plume constituents $\left(\mathrm{O}_{3}, \mathrm{AOD}, \mathrm{CO}, \mathrm{NO}_{2}\right.$, and $\left.\mathrm{CH}_{4}\right)$ and a variety of MERRA-2 meteorological parameters averaged over the southern Amazon were extracted for the highest season on record, August-October 2007 (cf. Table 2): near-surface temperature, specific humidity, and winds; 500-hPa vertical motion and geopotential height; potential evaporation/transpiration; and surface air pressure. Daily pairwise cross correlations were calculated for the 2007 dry season to determine influences on dispersion, where $90 \%$ confidence is reached with $r>|0.50|$ for a sample size of 90 days.

For the month with highest $\mathrm{CO}$ concentration, September 2007 (cf. Fig. 3a), vertical sections of CALIPSO aerosol density were obtained for 2 September and 9 September 2007. HYSPLIT simulated dispersion for a continuous emission at $10^{\circ} \mathrm{S}, 55^{\circ} \mathrm{W}$ at $1000-\mathrm{m}$ elevation in the period $15-18$ September 2007, similar to Magalhães et al. (2019). HYSPLIT (Stein et al. 2015) represents the Lagrangian diffusion of pollutants within a specified period by weather data assimilation. To determine whether the smoke plume affects local climate, a brief trend analysis was calculated by linear regression of annual NOAA (no-noise, smoothed, brightness temperature: "SMT") vegetation temperature, and NCEP2 air temperature and wind circulation 1980-2018. The slope (e.g., $d T / d t$ ) is spatially mapped over the southern Amazon region. The hypothesis is that a faster rate of warming will emerge in areas covered by smoke plumes.
We note that policies aimed at controlling emissions may affect variability or trends that are beyond the scope of research.

\section{Results}

\section{a. Mean patterns: Air constituents}

Figure 1 characterizes the mean trace gas and aerosol footprints in the study period 2000-18. The annual mean MOPITT

TABLE 2. Correlation of daily near-surface air constituents and meteorological conditions averaged over the southern Amazon index area for 1 Aug-31 Oct 2007; meteorological $r$ values above $90 \%$ confidence with $N=90$ are shown with boldface font. Air constituents are illustrated in Fig. 5a. Meteorological parameters are as follows: $500 \mathrm{~W}=500-\mathrm{hPa}$ vertical motion, with positive values indicating sinking; deltaT $=850-\mathrm{hPa}$ temperature minus surface temperature, with positive values indicating stable air; $\mathrm{U} 850=850-\mathrm{hPa}$ zonal wind, with negative values indicating wind from the east; $\mathrm{V} 850=850-\mathrm{hPa}$ meridional wind, with negative values indicating wind from the north; Q925 $=925-\mathrm{hPa}$ specific humidity; transpir = latent heat flux, with positive values indicating upward flux; Tmin $=$ minimum surface temperature.

\begin{tabular}{lrrrrr}
\hline \hline & $\mathrm{CO}$ & $\mathrm{AOD}$ & \multicolumn{1}{c}{$\mathrm{O}_{3}$} & $\mathrm{CH}_{4}$ & $\mathrm{NO}_{2}$ \\
\hline $\mathrm{AOD}$ & 0.68 & & & & \\
$\mathrm{O}_{3}$ & 0.92 & 0.53 & & & \\
$\mathrm{CH}_{4}$ & 0.44 & 0.63 & 0.31 & & \\
$\mathrm{NO}_{2}$ & 0.63 & 0.66 & 0.60 & 0.47 & \\
$500 \mathrm{~W}$ & 0.04 & 0.45 & -0.13 & 0.38 & 0.18 \\
DeltaT & $\mathbf{- 0 . 7 8}$ & $\mathbf{- 0 . 5 4}$ & $\mathbf{- 0 . 7 3}$ & -0.42 & -0.37 \\
U850 & 0.36 & 0.04 & 0.44 & 0.01 & -0.03 \\
V850 & -0.27 & -0.08 & -0.28 & -0.22 & -0.05 \\
Q925 & $\mathbf{0 . 5 4}$ & -0.01 & $\mathbf{0 . 6 5}$ & -0.07 & 0.10 \\
Transpir & $\mathbf{0 . 5 6}$ & 0.01 & $\mathbf{0 . 7 5}$ & -0.05 & 0.21 \\
Tmin & $\mathbf{0 . 8 1}$ & 0.14 & $\mathbf{0 . 8 1}$ & 0.32 & 0.49 \\
\hline & & & & &
\end{tabular}


CO distribution (Fig. 1a) exceeds 100 ppb over the center of South America $\left(10^{\circ} \mathrm{S}, 60^{\circ} \mathrm{W}, 900 \mathrm{hPa}\right)$ where winds are westward at $\sim 4 \mathrm{~m} \mathrm{~s}^{-1}$. There is a remnant CO plume from Africa $\left(5^{\circ} \mathrm{N}, 30^{\circ} \mathrm{W}\right)$. In the north-south section (Fig. 1b) the $\mathrm{CO}$ maximum below $600 \mathrm{hPa}$ at $10^{\circ}-15^{\circ} \mathrm{S}$ is drawn poleward by the subtropical jet stream (Garreaud and Aceituno 2001), and the east-west section illustrates the $\mathrm{CO}$ maximum spreading westward (Fig. 1c). The mean zonal circulation weakens to $\sim 1 \mathrm{~m} \mathrm{~s}^{-1}$ on approaching the Andes Mountains, accumulating smoke plumes over Rondonia, Mato Grosso, and the Pantanal.

The aerosol footprint (AOD; Fig. 1d) is concentrated over the same southern Amazon area as $\mathrm{CO}$ - that is, $5^{\circ}-15^{\circ} \mathrm{S}, 50^{\circ}$ $70^{\circ} \mathrm{W}$-following southwestward dispersion from eastern Brazil by anticyclonic winds. The CALIPSO extinction profile (Fig. 1e) shows a dense surface layer, low values $\sim 1 \mathrm{~km}$ above ground, and then a prominent aerosol layer at $2 \mathrm{~km}$, which tapers off above $4 \mathrm{~km}$, similar to Gonzalez-Alonso et al. (2019). From the profile, we infer that buoyant smoke plumes rise into the 1000-3000-m layer during initial dispersion. The Global Fire Emission Database counts 200 000 fires annually within the southern Amazon area, consistent with earlier findings of Potter et al. (2002).

\section{b. Mean patterns: Fire emissions}

In Fig. 2 we characterize land temperatures and fire emissions. The MODIS daytime land surface temperature map for July-October (Fig. 2a) shows a distinct east-west axis $>40^{\circ} \mathrm{C}$ on $10^{\circ} \mathrm{S}$ extending from $40^{\circ}$ to $60^{\circ} \mathrm{W}$ (cf. Morgan et al. 2019). The satellite fire map (Fig. 2b) reveals dense concentration along the same east-west axis, upwind of the CO and AOD footprints as expected from dispersion. Its mean annual cycle averaged over the southern Amazon (Fig. 2c) shows that fire density and emissions rise suddenly in July, peak in AugustSeptember, and decline rapidly in October. Fire counts are very low from November to June because of moist soil and vegetation. Morgan et al. (2019) demonstrate a tight relationship ( $r^{2}$ of $0.57-0.86$ ) between fire counts and AOD over the southern Amazon.

\section{c. Temporal features and annual cycle}

The time series of near-surface $\mathrm{CO}$ and AOD over the southern Amazon is given in Fig. 3a. Sharp seasonal peaks are evident; highest monthly values came in September 2007 as a Pacific La Niña developed (NOAA 2007). The smoke constituents show insignificant downward trends $\left(r^{2}<0.023\right)$ in contrast with Morgan et al. (2019). The mean annual cycle of air constituents demonstrates how the fire emissions accumulate over the southern Amazon (Fig. 3b). Values rise for $\mathrm{CH}_{4}$ after June, peak for $\mathrm{CO}$ and $\mathrm{NO}_{2}$ in September, and continue high for $\mathrm{AOD} / \mathrm{O}_{3}$ into October. The air is relatively free of smoke plumes during and after the wet season. The net OLR annual cycle (Fig. 3c) reflects low values under cloudy skies (November-April) and high values in austral winter (JuneAugust) that contribute to desiccation.

\section{d. Interannual variability}

Lag correlation of July-October 2000-18 CO values over the southern Amazon with local and regional variables is
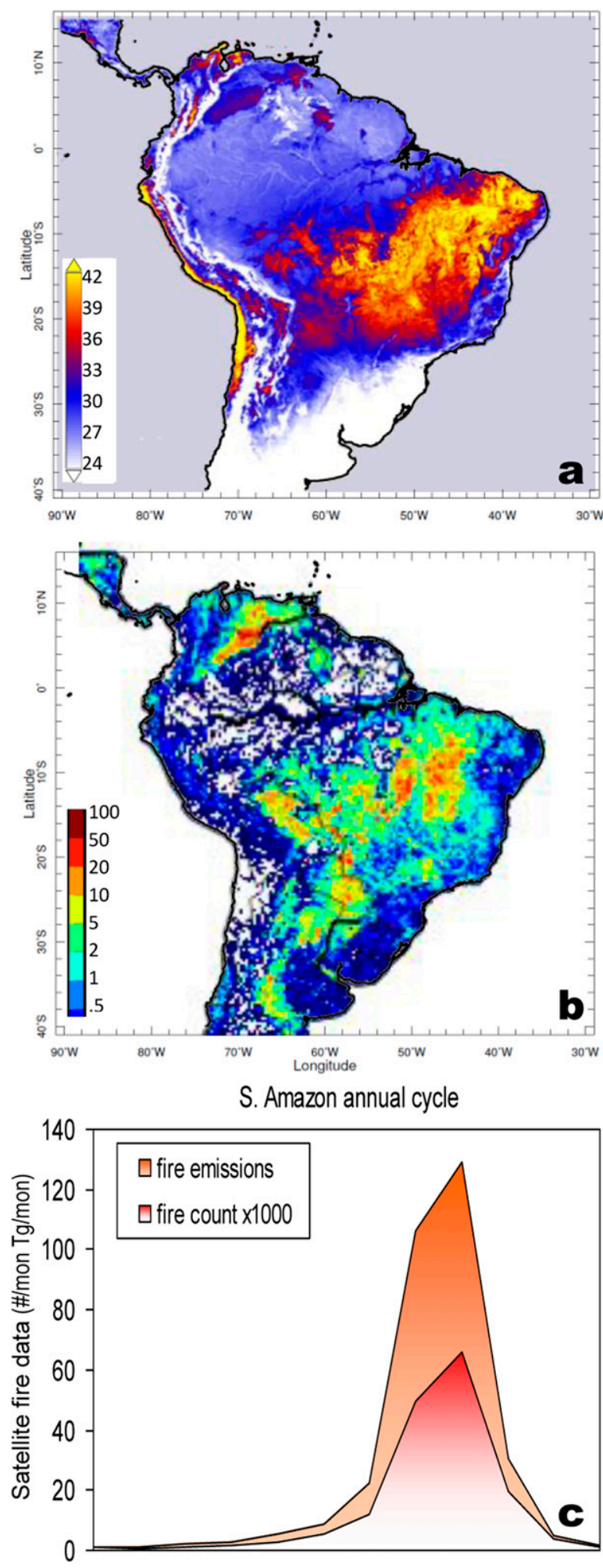

jan feb mar apr may jun jul aug sep oct nov dec

FIG. 2. July-October mean MODIS satellite: (a) land surface temperature shaded above $24^{\circ} \mathrm{C}$ and (b) fire count density. (c) Mean annual cycle of fire count (number per month $\times 1000)$ and emissions $(\mathrm{Tg}$ month $\left.{ }^{-1}\right)$ within the southern Amazon index area $\left(\sim 2.4 \times 10^{6} \mathrm{~km}^{2}\right)$. 

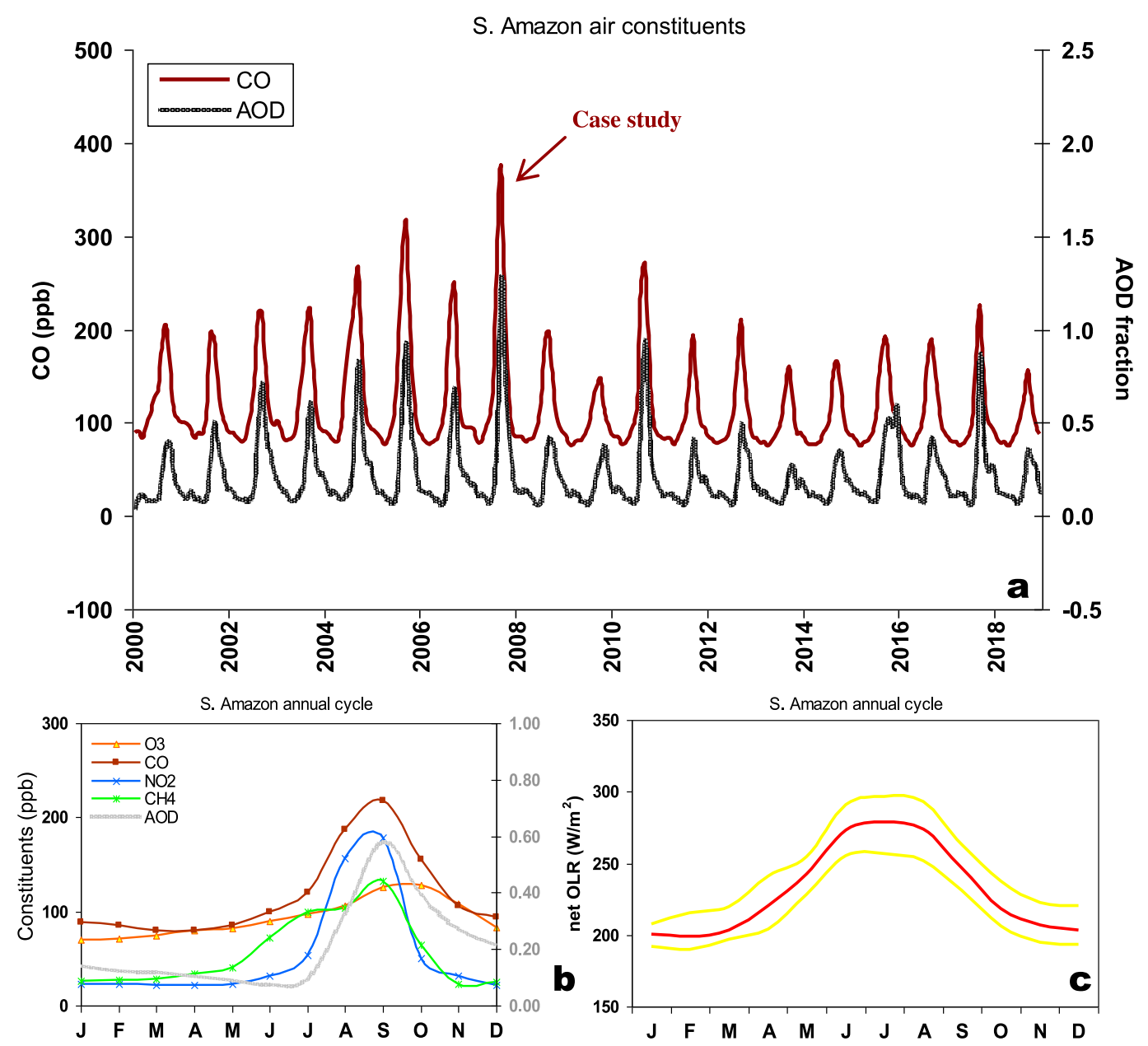

FIG. 3. (a) Time series of near-surface CO concentration and AOD fraction over the southern Amazon, and case study. Also shown is the mean annual cycle of (b) near-surface air constituents (ppb) and AOD (second $y$ axis) and (c) net OLR as a proxy for dryness (red is the mean, and yellow indicates the upper and lower quintiles).

presented in Figs. 4a-c. For Niño-3 Pacific SST, the correlations are negative (e.g., La Niña enhancement) before and during the burning season $(r<-0.4$ from -8 to +2 months). Thereafter, the SST correlation rises. The CO lag correlation with local soil moisture is negative during the burning season (0 lag), but neutral before to positive after. Similarly, the CO lag correlation with local vegetation is negative during the season. However, in the preceding (-9) and following $(+6)$ months the vegetation is positively correlated, indicating that the fuel available for fire emissions is enhanced with respect to July-October CO concentrations. Chen et al. (2017) point out that increased biomass in the preceding and following year may contribute to a cascade of fire emissions. The narrow dip in the CO-vegetation graph (Fig. 4c) supports this idea.

Using the times series of southern Amazon CO for JulyOctober 2000-18, it is evident from the field correlation maps (Figs. 4d-f) that cooler sea temperatures and higher pressure in the east Pacific Ocean enhance fire emissions, consistent with La Niña (Andreoli et al. 2018). 500-hPa zonal wind correlations indicate westerlies $(+r)$ over Peru and easterlies $(-r)$ over Brazil: opposing flows that confine the smoke plumes. Correlation of July-October CO data with fields of satellite vegetation and soil moisture (Figs. $4 \mathrm{~g}, \mathrm{~h})$ show wet conditions north $\left(10^{\circ} \mathrm{N}\right)$ and south $\left(35^{\circ} \mathrm{S}\right)$, and dry conditions across the zone of greatest fire emissions $\left(5^{\circ}-20^{\circ} \mathrm{S}\right)$ as expected. The temporal and spatial statistics reveal interannual climate modulation of trace gas concentrations derived from biomass burning, notably enhancement by La Niña.

\section{e. Intraseasonal fluctuations: August-October 2007}

The case of high CO concentrations during onset of Pacific La Niña from August to October 2007 provides an intraseasonal focus. Figure 5a shows the upper winds and humidity and identifies the passage of three Rossby waves in the upper westerlies and two spells of intensified easterlies. The second Rossby wave in mid-September is preceded by weak winds, while the third Rossby wave in early October is followed by a jump in humidity. Intraseasonal changes in 

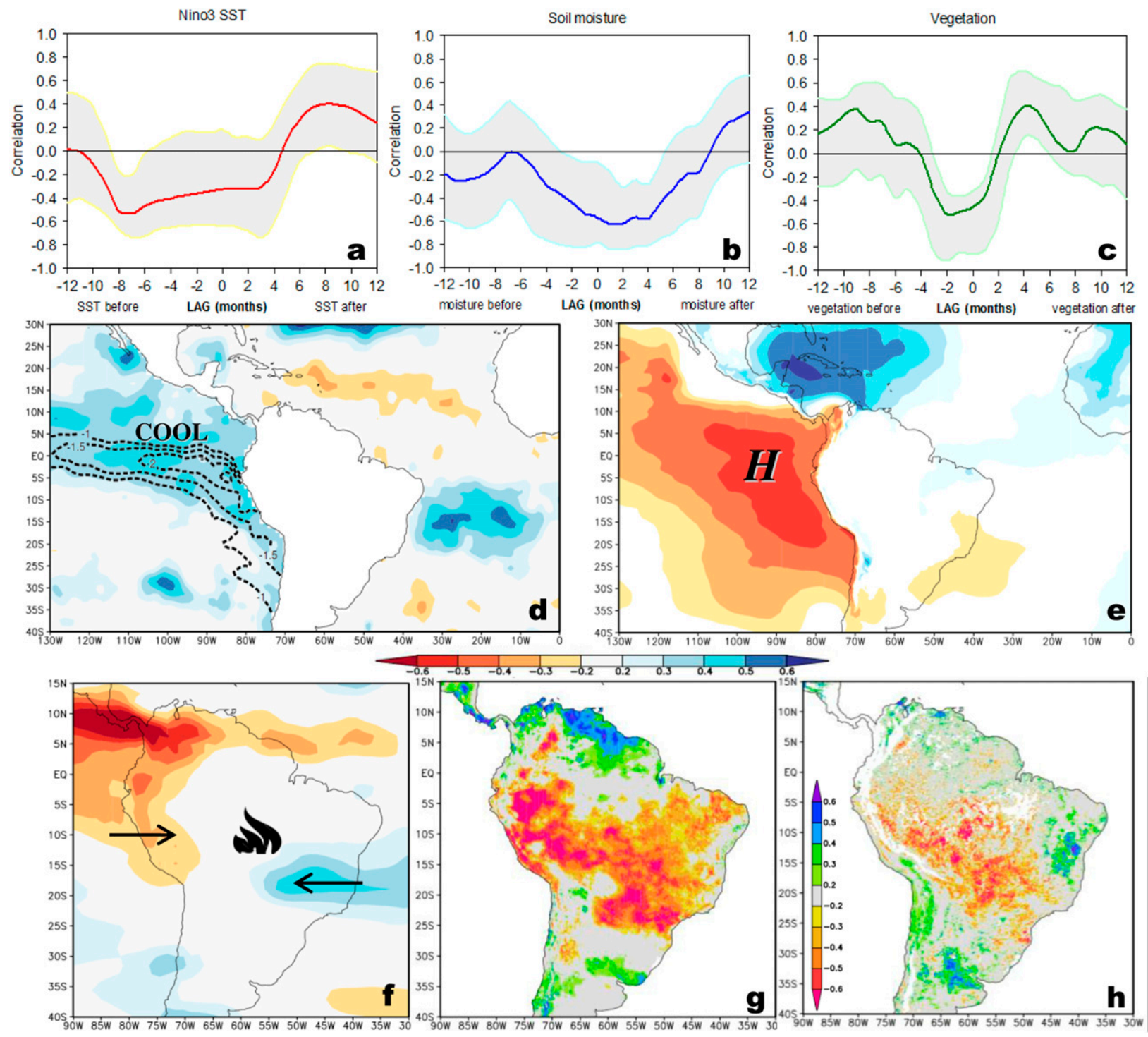

FIG. 4. Interannual lag correlation of southern Amazon July-October CO values with (a) Niño-3 Pacific SST, (b) local soil moisture, and (c) local vegetation fraction, from 12 months before (negative $x$ axis) to after, with 95\% confidence envelope. Also shown is the interannual correlation of July-October 2000-18 CO concentrations (peaks in Fig. 3a) onto (d) NOAA sea surface temperature, (e) MERRA-2 surface air pressure, (f) 500-hPa zonal wind (with the fire icon at the maximum), (g) soil moisture, and (h) NOAA vegetation with reversed scale. Dashed lines over the correlation shading in (d) refer to August-October 2007 SST anomalies.

dispersion can be traced to the upper "jet" and cool east Pacific SST (cf. Fig. 4d).

Daily fluctuations are evident in the time series of air constituents and weather parameters in Figs. 5b-d. There is a slow rise of trace gases and aerosols associated with smoke plumes during August, then three major AOD/NO2 pulses in September, followed by a decline in October 2007. The smoke plumes dispersed within dry weather, sinking motions, stable lapse rates and vigorous easterly winds in August and early September 2007. Fluctuations of lapse rate and zonal wind precede peaks in pollutant concentration by a few days, associated with the abovementioned passage of midlatitude perturbations. A final dry spell at the end of September 2007 is followed by rising motion, greater humidity, and weak winds during October 2007, conditions that tend to suppress fire emissions.

Daily pairwise cross correlations are listed in Table 2 and reveal some expected results and a few surprises. The air constituents show agreement with each other, reaching $r=0.92$ for near-surface $\mathrm{CO}$ and $\mathrm{O}_{3}$. Subsidence at $500 \mathrm{hPa}$ (positive $500 \mathrm{~W})$ increases $\mathrm{AOD}$ and $\mathrm{CH}_{4}(+r)$ but not other constituents. Northwesterly flow $(+U$ and $-V)$ accumulates $\mathrm{CO}$ and $\mathrm{O}_{3}$ but has little effect on other constituents. The deltaT (lapse rate) shows negative association; hence unstable conditions 

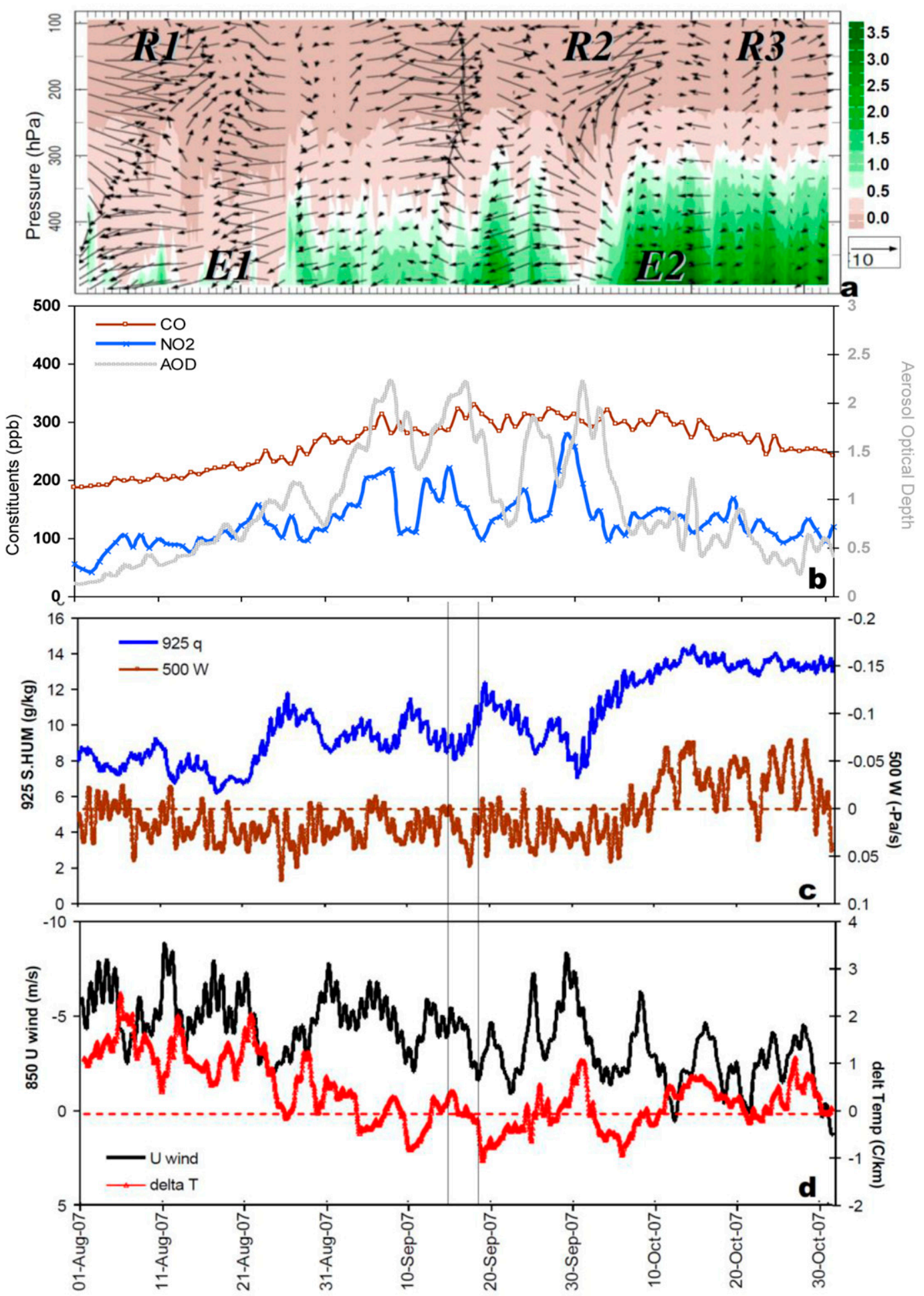

FIG. 5. (a) Height-time section from 5 to $15 \mathrm{~km}(500-100 \mathrm{hPa})$ of upper-wind vectors $\left(\mathrm{m} \mathrm{s}^{-1}\right)$ and specific humidity $\left(\mathrm{g} \mathrm{kg}^{-1}\right.$ ) in August-October 2007, showing passing Rossby waves (R) and easterlies (E). Daily time series (August-October 2007) over the southern Amazon area of (b) near-surface air constituents (ppb; AOD uses second $y$ axis), (c) 925-hPa specific humidity and (inverted) 500-hPa vertical motion (below dashed line indicates sinking), and (d) (inverted) $850-\mathrm{hPa} U$ wind and $850-1000-\mathrm{hPa}$ temperature anomaly (positive values indicate stable air). The time axis at the bottom of the figure applies to all panels, and vertical lines enclose the dispersion simulation on 15-18 Sep. Daily correlations are listed in Table 2. 

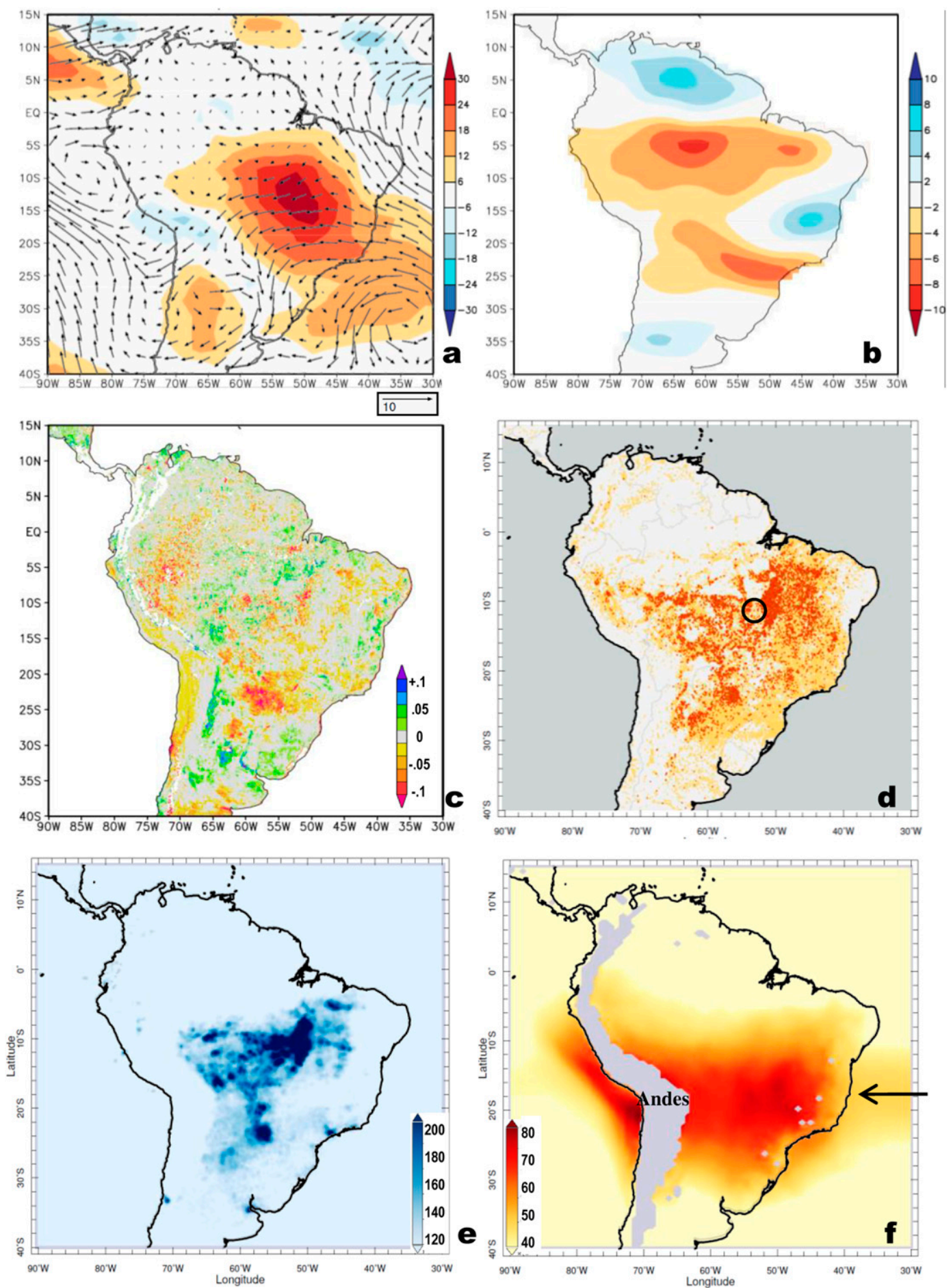

FIG. 6. August-October 2007 high-case mean (a) net OLR anomaly $\left(\mathrm{W} \mathrm{m}^{-2}\right)$ and 925-700-hPa wind anomalies $\left(\mathrm{m} \mathrm{s}^{-1}\right.$ ), (b) GRACE soil water anomaly $(\mathrm{cm})$, (c) NOAA satellite vegetation anomaly, (d) MODIS fire-burn intensity shaded from yellow to orange (indicating the nocturnal fire temperature range as estimated by satellite IR), and HYSPLIT simulation point (circle), (e) OMI tropospheric $\mathrm{NO}_{2}$ concentration (ppb), and (f) MERRA-2 $\mathrm{O}_{3}$ concentration at $900 \mathrm{hPa}(\mathrm{ppb})$, with the large arrow referring to smoke plumes from southern Africa. 

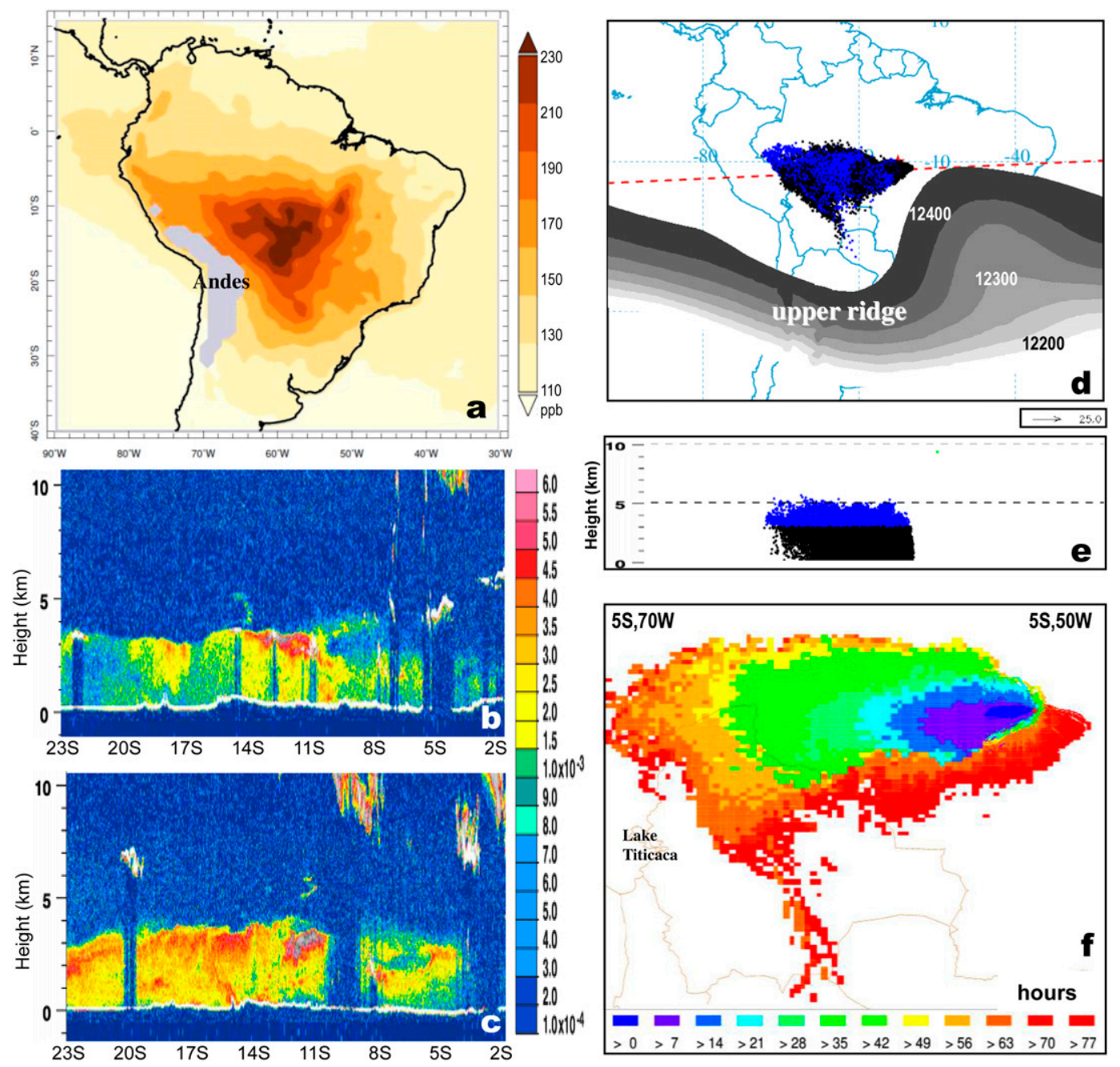

FIG. 7. (a) September 2007 mean MOPITT CO concentration at $900 \mathrm{hPa}$ (ppb). South-north slices of CALIPSO lidar aerosol density (b) along $57^{\circ} \mathrm{W}$ on 2 Sep 2007 and (c) along $60^{\circ} \mathrm{W}$ on 9 Sep 2007, illustrating the depth of the smoke plume (based on backscatter at $1.064 \mu \mathrm{m}$ ); HYSPLIT-simulated dispersion over 3 days from 0000 UTC 15 Sep 2007 with source at $10^{\circ} \mathrm{S}, 55^{\circ} \mathrm{W}$ at 1000 -m elevation, showing (d) the map and (e) an west-east section (black below $3 \mathrm{~km}$ ). (f) Smoke-plume arrival times with expanded scale. Overlaid in (d) are 200-hPa geopotential heights from 12200 to $12400 \mathrm{~m}$, showing the upper ridge.

due to surface heating favor increased emissions/decreased dispersion. Another surprising result is that humidity and transpiration relate to greater trace gases and aerosols over the southern Amazon in the August-October 2007 period. A few caveats apply: (i) humidity affects satellite retrievals, (ii) constituent residence time alters sensitivity and response, and (iii) radiative feedback is just as likely as weather forcing.

\section{f. Spatial analysis: August-October 2007}

Figures $6 a-d$ illustrates the anomaly patterns during this case, based on the departure from the 2000-18 mean. The net OLR shows an anomalous warm dry area over much of Brazil under easterly flow, while the GRACE satellite soil moisture has two dry areas: $5^{\circ}-10^{\circ} \mathrm{S}$ near the Amazon and a northwest axis at $20^{\circ}-25^{\circ} \mathrm{S}$. NOAA satellite vegetation anomalies are negative (dry) over Brazil, Peruvian lowlands, and the Parana River valley $\left(22^{\circ} \mathrm{S}, 57^{\circ} \mathrm{W}\right)$; in contrast with weak values near the Amazon River. The west negative/east positive pattern across the southern Andes relates to orographic clouds on windward slopes. The fire density map follows the net OLR pattern with burning across the area $5^{\circ}-25^{\circ} \mathrm{S}, 45^{\circ}-65^{\circ} \mathrm{W}$. MODIS fire statistics indicate a mean duration of 5-10 days and average individual size of $10-20 \mathrm{~km}^{2}$. The August-October 2007 mean OMI tropospheric $\mathrm{NO}_{2}$ and MERRA-2 900-hPa $\mathrm{O}_{3}$ maps (Figs. 6e,f) show different stages of smoke-plume dispersion. $\mathrm{NO}_{2}$ concentrations are greatest over the fires of Brazil, whereas the near-surface ozone spreads southwest after aging and anticyclonic transport. Along with the local smoke 

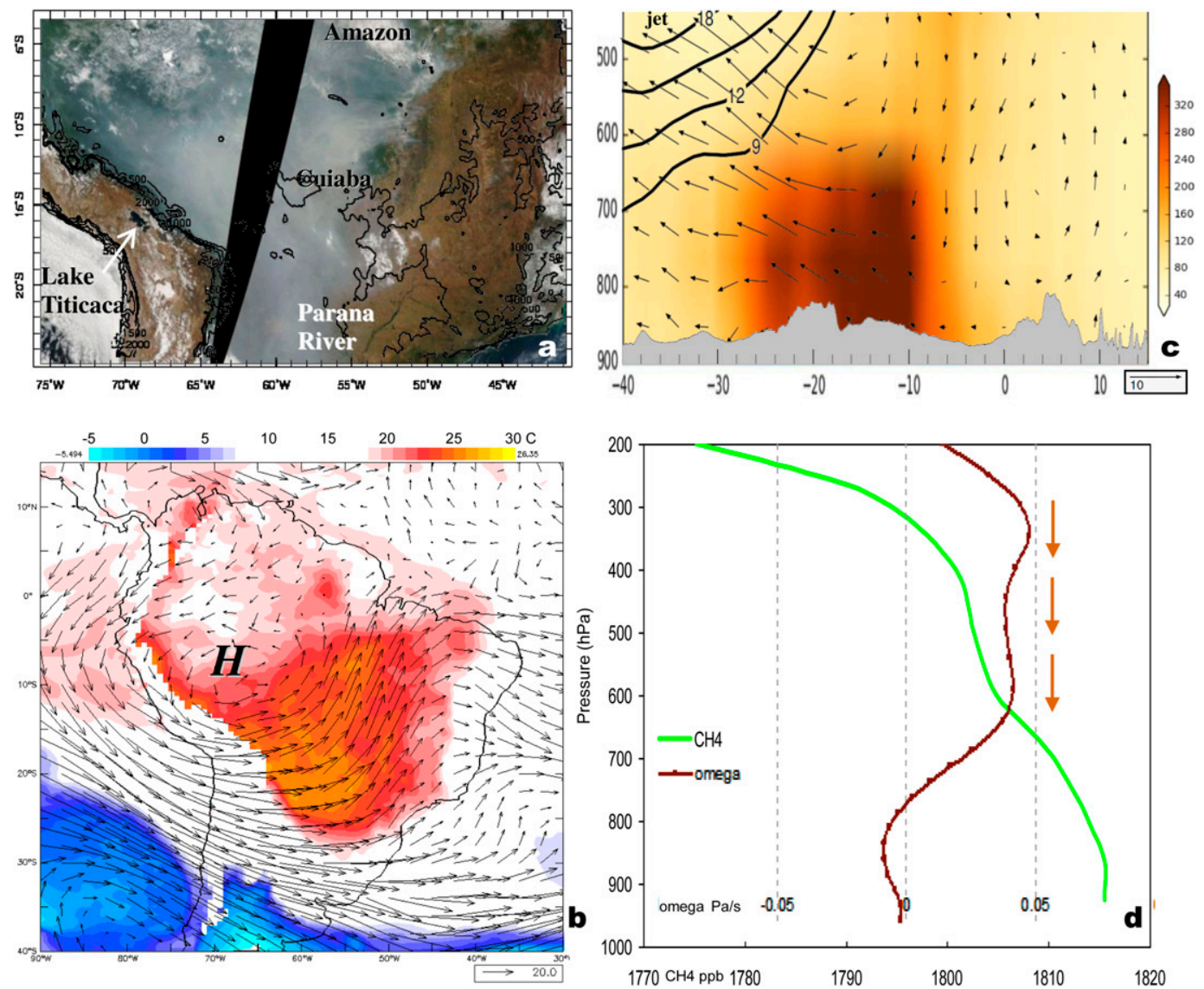

FIG. 8. Maps for 14 Sep 2007 of (a) a MODIS visible image of the smoke plume with topographic details and (b) MERRA-2 near-surface 850-hPa temperature (shaded) and upper 200-hPa winds (vectors). Also shown are mean September 2007 conditions: (c) south-north section $55^{\circ}-65^{\circ} \mathrm{W}$ of MOPITT CO (ppb) and NCEP2 meridional circulation vectors and upper-jet contours and (d) profiles of MERRA-2 vertical motion (red, labeled omega; $\mathrm{Pa} \mathrm{s}^{-1}$ ) and AIRS $\mathrm{CH} 4$ concentration (ppb; green). Positive omega refers to sinking motions (as indicated by the arrows).

plume, some of the secondary $\mathrm{O}_{3}$ arrives from southern Africa $\left(18^{\circ} \mathrm{S}, 30^{\circ} \mathrm{W}\right)$ and passes over the Andes to the west coast.

High concentrations of $\mathrm{CO}$ are evident across the center of South America in September 2007 (Fig. 7a). The CALIPSO sections (Figs. $7 \mathrm{~b}, \mathrm{c}$ ) illustrate the buildup of smoke plumes from 2 to 9 September 2007 : initially $11^{\circ}-14^{\circ} \mathrm{S}$, spreading to $5^{\circ}-$ $23^{\circ} \mathrm{S}$. The lidar sections reveal that smoke-plume aerosols are vertically dense from surface to $4 \mathrm{~km}$; the top of the boundary layer is sharply limited by subsidence. The HYSPLIT simulated dispersion from a continuous emission at $10^{\circ} \mathrm{S}, 55^{\circ} \mathrm{W}$ at $1000-\mathrm{m}$ elevation in the period 15-18 September 2007 is westward (Fig. 7d), but after spreading by $10^{\circ}$ latitude and $20^{\circ}$ longitude, the plume is blocked by the Andes Mountains and accumulates over the lowlands of Bolivia. Of interest is the upper geopotential pattern driving a fast jet stream along $30^{\circ} \mathrm{S}$ latitude and an anticyclonic ridge downstream. The HYSPLIT vertical dispersion (Fig. 7e) slightly exceeds the depth observed by CALIPSO: 5 versus $4 \mathrm{~km}$. Plume arrival times (Fig. 7f) quantify westward expansion on 15-16 September 2007, followed by a slowing over the foothills of the Andes on 17 September. The 200-hPa flow imparts anticyclonic vorticity of $\sim 10^{-4} \mathrm{~s}^{-1}$ and sinking motions that prevent upward diffusion. Hence there is a stagnation of flow that accumulates pollutants beneath a subsiding layer.

Dense smoke plumes are evident in the MODIS visible image of 14 September 2007 (Fig. 8a) between fire emissions at $55^{\circ} \mathrm{W}$ and the Andes at $65^{\circ} \mathrm{W}$. Upper winds and near-surface temperatures on 14 September 2007 (Fig. 8b) reflect the jet stream at $30^{\circ} \mathrm{S}$ curving equatorward over a warm circular area where the smoke plumes are confined to $15^{\circ} \mathrm{S}$. Cuiaba, Brazil, is centrally located $\left(15^{\circ} \mathrm{S}, 56^{\circ} \mathrm{W}\right)$, and its radiosonde profile on 14 September 2007 (Table 3) lists weak northerly winds below $700 \mathrm{hPa}$. A hot dry layer is present from 975 to $925 \mathrm{hPa}$ with temperature $T>30^{\circ} \mathrm{C}$ and dewpoint $\mathrm{Td}<5^{\circ} \mathrm{C}$. Above $600 \mathrm{hPa}$, the $T-\mathrm{Td}$ difference exceeds $30^{\circ} \mathrm{C}$, indicative of extraordinary subsidence during this episode. Southeasterly winds above $600 \mathrm{hPa}$ disperse some of the fire emissions toward Bolivia. 
TABLE 3. Cuiaba radiosonde profile at 0000 UTC 14 Sep 2007. Large differences between temperature and dewpoint within the boundary layer indicate subsiding air. For wind speed, $1 \mathrm{kt}=0.51 \mathrm{~m} \mathrm{~s}^{-1}$.

\begin{tabular}{|c|c|c|c|c|c|}
\hline Pressure $(\mathrm{hPa})$ & Height (m) & Temperature $\left({ }^{\circ} \mathrm{C}\right)$ & Dewpoint $\left({ }^{\circ} \mathrm{C}\right)$ & Wind direction $\left(^{\circ}\right)$ & Wind speed (kt) \\
\hline 500 & 5880 & -5.9 & -53.9 & 185 & 7 \\
\hline 528 & 5450 & -3.5 & -52.0 & 185 & 99 \\
\hline 549 & 5143 & -1.7 & -50.7 & 159 & 12 \\
\hline 568 & 4872 & -2.3 & -30.3 & 136 & 15 \\
\hline 572 & 4817 & -2.7 & -19.7 & 131 & 15 \\
\hline 595 & 4504 & -2.0 & -9.6 & 105 & 18 \\
\hline 608 & 4331 & -1.1 & -4.6 & 100 & 17 \\
\hline 655 & 3731 & 4.0 & -3.0 & 84 & 12 \\
\hline 700 & 3185 & 9.2 & -1.8 & 70 & 7 \\
\hline 768 & 2406 & 16.6 & -2.4 & 35 & 8 \\
\hline 819 & 1852 & 21.8 & -0.4 & 10 & 8 \\
\hline 850 & 1531 & 24.8 & 0.8 & 5 & 9 \\
\hline 925 & 782 & 31.8 & 3.8 & 355 & 14 \\
\hline 945 & 587 & 33.3 & 4.1 & 355 & 15 \\
\hline 975 & 303 & 35.6 & 4.6 & 351 & 7 \\
\hline 988 & 182 & 33.0 & 10.0 & 350 & 4 \\
\hline
\end{tabular}

The mean $\mathrm{CO}$ concentration and meridional circulation during September 2007 (Fig. 8c) reflects sinking motions over southern Amazon fires and poleward transport. Greatest $\mathrm{CO}$ values are found in the $900-600-\mathrm{hPa}$ layer from $10^{\circ}$ to $26^{\circ} \mathrm{S}$, adjacent to the upper jet. The MERRA-2 vertical motion profile averaged over the southern Amazon in September 2007 (Fig. 8d) reveals a deep layer of subsidence from 700 to $300 \mathrm{hPa}$, which confines high $\mathrm{CH}_{4}$ concentrations in the layer beneath.

\section{g. Climate trends}

Linear trends of NCEP2 air temperature and the meridional circulation in the period 1980-2018 are given in Fig. 9a and show a warming rate of $+0.03^{\circ} \mathrm{C} \mathrm{yr}^{-1}$ that tilts poleward with height, consistent with smoke-plume constituents, circulation trends and Magrin et al. (2014) projections. Trace gases from biomass burning correspond with faster atmospheric warming, and areas of dense fires coincide with faster surface warming $\left(+0.1^{\circ} \mathrm{Cyr}^{-1}\right.$; Fig. 9b). This points to human-altered landscapes and associated moist energy imbalance (Cochrane and Laurance 2008). As listed in Table 2, minimum temperatures tend to rise under higher $\mathrm{CO}$ and $\mathrm{O}_{3}$ concentrations $(r=0.81)$, suggesting that smoke-plume constituents absorb nocturnal radiation. There are two unexpected results: (i) a high rate of vegetation warming over the Andes Mountains and Argentina and (ii) a near-zero trend in the equatorial zone. Brando et al. (2020) provide an analysis of climate trends and projections, and they conclude that locally faster warming of the air and land will contribute to forest flammability, smoke emissions, and drought.

\section{Conclusions}

The atmospheric dispersion of smoke plumes over South America has been analyzed via trace gas and aerosol "footprints" seen by satellites and air chemistry reanalysis. Carbon monoxide concentrations and AOD over and west of fire emissions from the area $5^{\circ}-15^{\circ} \mathrm{S}, 50^{\circ}-70^{\circ} \mathrm{W}$ double in value from the wet season to the dry season and assume a circular shape (cf. Figs. 1a, 2a, 7a). Correlation of CO values onto fields of SST and air pressure show a cool eastern Pacific Ocean overlain with high pressure. Opposing midlevel winds accumulate trace gases (cf. Fig. 4c) while a drier surface stimulates fire emissions (cf. Figs. 4d,e), for example in September 2007. Low-level winds transport smoke plumes from eastern Brazil toward the foothills of the Andes, where they tend to stagnate and recirculate southward. Anticyclonic ridging of the jet stream imparts sinking motions that confine the smoke plumes below $4 \mathrm{~km}$.

Land and air temperatures appear to be rising faster in burned zones and in smoke plumes with high $\mathrm{AOD}, \mathrm{CO}, \mathrm{NO}_{2}$ concentration (cf. Figs. 1b, 9a). Particulate scattering can oppose trace gas absorption of radiation (Li et al. 2000; Jury and Whitehall 2010; Magrin et al. 2014). Palácios et al. (2020) measured aerosol size distributions in the southern Amazon and found peaks of 0.15 and $5.0 \mu \mathrm{m}$ that contributed to surface cooling. Procopio et al. (2004) quantified the radiative impacts of smoke plumes and found a net flux of $+30 \mathrm{~W} \mathrm{~m}^{-2}$ in the dry season, within aged fire emissions dominated by $\mathrm{CO}_{2}$ (Levine 2003). Here the collocation of smoke-plume constituents, land surface warming and rising air temperatures suggest that heat-trapping trace gases overwhelm the scattering effect of coarse aerosols, seasonal wet deposition, and feedbacks (Morgan et al. 2019) and drive net radiative absorption.

Most fires are initiated by forest to farmland conversion to feed the appetite of a growing population. Land management advice across South America is helping to level off trace gas emissions, yet respiratory health impacts are ongoing (Butt et al. 2020). Local warming rates of $+0.03^{\circ} \mathrm{C} \mathrm{yr}^{-1}$ in the air and $+0.1^{\circ} \mathrm{Cyr}^{-1}$ at the land surface (Figs. 9a,b) rank in the top $1 \%$ globally. 

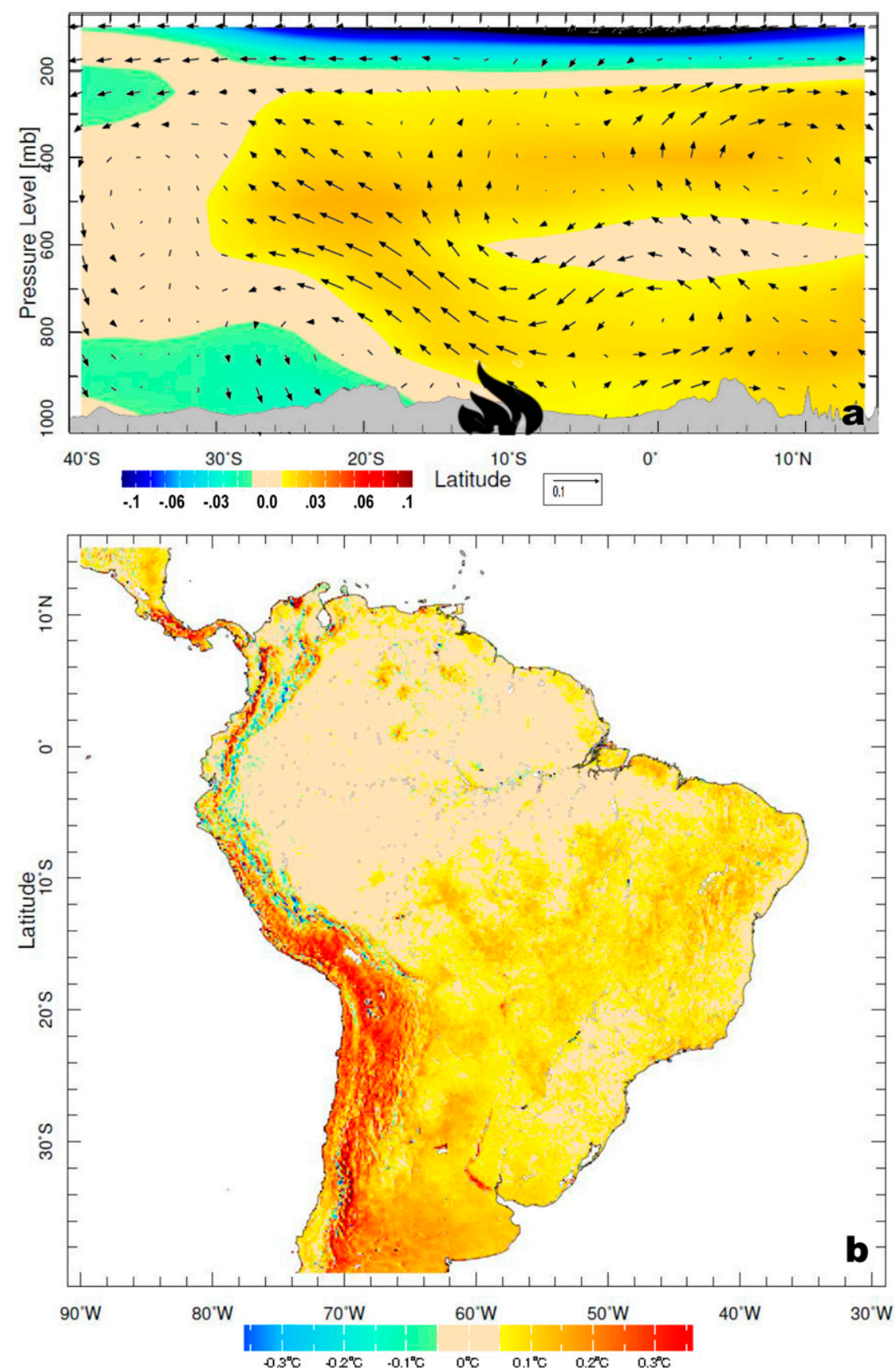

FIG. 9. Linear trend over 1980-2018 of annual (a) NCEP2 air temperature (shading; ${ }^{\circ} \mathrm{C} \mathrm{yr}^{-1}$ ) and meridional circulation (vectors; $\mathrm{m} \mathrm{s}^{-1} / \mathrm{yr}$ ) on a south-north slice averaged over $55^{\circ}-65^{\circ} \mathrm{W}$ and (b) SMT. Burned areas and the southern Andes show warming trends $>+0.1^{\circ} \mathrm{Cyr}^{-1}$. The fire icon in (a) represents the latitude of maximum fire density.

Our study suggests that weather conditions promoting fire emissions also limit the dispersion via stagnation of flow beneath a subsiding layer. Smoke plumes blanketed many cities surrounding the southern Amazon in 2019 (Fig. 10), prompting widespread concern and calls to limit biomass burning deforestation.
Acknowledgments. Satellite and reanalysis air chemistry data were obtained from NASA-Giovanni. Atmospheric data were analyzed via the University of Hawai'i APDRC, KNMI Climate Explorer, and IRI Climate Library; the HYSPLITsimulated dispersion was conducted in NOAA Ready-ARL. A data spreadsheet is available on request. 

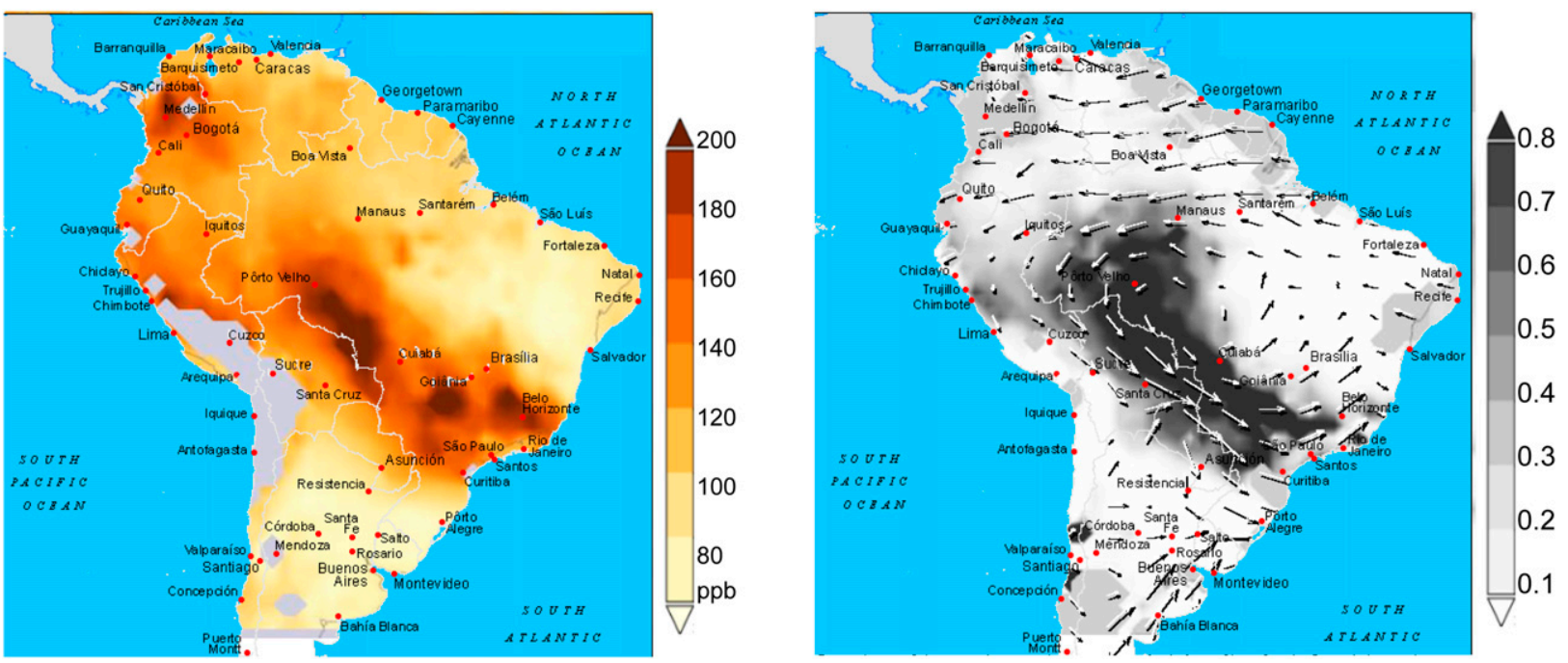

FIG. 10. (left) MOPITT CO concentration and (right) 700-hPa winds over MODIS AOD, when the smoke plume reached eastern Brazil's major cities on 19 Aug 2019. Values over the sea are masked.

\section{REFERENCES}

Acker, J. G., and G. Leptoukh, 2007: Online analysis enhances use of NASA Earth science data. Eos, Trans. Amer. Geophys. Union, 88, 14-17, https://doi.org/10.1029/2007EO020003.

Amiridis, V., and Coauthors, 2015: LIVAS: A 3-D multiwavelength aerosol/cloud database based on CALIPSO and EARLINET. Atmos. Chem. Phys., 15, 7127-7153, https:// doi.org/10.5194/acp-15-7127-2015.

Andreae, M. O., 2019: Emission of trace gases and aerosols from biomass burning-An updated assessment. Atmos. Chem. Phys., 19, 8523-8546, https://doi.org/10.5194/acp-19-8523-2019.

Andreoli, R. V, M. T. Kayano, J. Viegas, S. S. de Oliveira, R. A. F. de Souza, S. R. Garcia, W. H. T. Rego, and M. B. L. de Oliveira, 2018: Effects of two different La Niña types on the South American rainfall. Int. J. Climatol., 39, 1415-1428, https://doi.org/10.1002/JOC.5891.

Artaxo, P., and Coauthors, 2002: Physical and chemical properties of aerosols in the wet and dry season in Rondônia, Amazonia. J. Geophys. Res., 107, 8081-8095, https://doi.org/10.1029/ 2001JD000666.

— , and Coauthors, 2013: Atmospheric aerosols in Amazonia and land use change: From natural biogenic to biomass burning conditions. Faraday Discuss., 165, 203-235, https://doi.org/ 10.1039/c3fd00052d.

Brando, P. M., and Coauthors, 2020: The gathering firestorm in southern Amazonia. Sci. Adv., 6, eaay1632, https://doi.org/ 10.1126/sciadv.aay1632.

Bucsela, E. J., and Coauthors, 2013: A new stratospheric and tropospheric $\mathrm{NO}_{2}$ retrieval algorithm for nadir-viewing satellite instruments, applications to OMI. Atmos. Meas. Tech., 6, 2607-2626, https://doi.org/10.5194/amt-6-2607-2013.

Butt, E. W., and Coauthors, 2020: Large air quality and human health impacts due to Amazon forest and vegetation fires. Environ. Res. Commun., 2, 095001, https://doi.org/10.1088/ 2515-7620/abb0db.

Chen, Y., D. Morton, N. Andela, G. Werf, L. Giglio, and J. Randerson, 2017: A pan-tropical cascade of fire driven by El Niño/Southern Oscillation. Nat. Climate Change, 7, 906-911, https://doi.org/10.1038/s41558-017-0014-8.
Cochrane, M. A., and W. F. Laurance, 2008: Synergisms among fire, land use, and climate change in the Amazon. Ambio, 37, 522-527, https://doi.org/10.1579/0044-7447-37.7.522.

Garreaud, R. D., and P. Aceituno, 2001: Atmospheric circulation over South America: Mean features and variability. The Physical Geography of South America, T. Veblen et al., Eds., Oxford University Press, 45-66.

Gonzalez-Alonso, L., M. Val Martin, and R. A. Kahn, 2019: Biomass-burning smoke heights over the Amazon observed from space. Atmos. Chem. Phys., 19, 1685-1702, https://doi.org/ 10.5194/acp-19-1685-2019.

IPCC, 2021: Climate Change and Land. P. R. Shukla et al., Eds., IPCC, www.ipcc.ch/srccl/, in press.

Jury, M. R., 2019: Northward excursion of the ITCZ across the inter-Americas during boreal summer. Meteor. Atmos. Phys., 131, 1357-1366, https://doi.org/10.1007/s00703-018-0642-1.

_ , and K. Whitehall, 2010: Warming of an elevated layer over Africa. Climatic Change, 99, 229-245, https://doi.org/10.1007/ s10584-009-9657-4.

Justice, C. O., and Coauthors, 2002: The MODIS fire products. Remote Sens. Environ., 83, 244-262, https://doi.org/10.1016/ S0034-4257(02)00076-7.

Kanamitsu, M., W. Ebisuzaki, J. Woollen, S. K. Yang, J. J. Hnilo, M. Fiorino, and G. L. Potter, 2002: NCEP-DOE AMIP-II Reanalysis (R-2). Bull. Amer. Meteor. Soc., 83, 1631-1644, https://doi.org/10.1175/BAMS-83-11-1631.

Kingtse, M., and E. Berbery, 2011: Drought and persistent wet spells over South America based on observations and the CLIVAR drought experiment. J. Climate, 24, 1801-1820, https://doi.org/10.1175/2010JCLI3874.1.

Levine, J. S., 2003: Biomass burning: The cycling of gases and particulates from the biosphere to the atmosphere. Treatise on Geochemistry, H. D. Holland and K. K. Turekian, Eds., Pergamon, 143-158.

Li, X., S. A. Christopher, J. Chou, and R. M. Welch, 2000: Estimation of shortwave direct radiative forcing of biomassburning aerosols using new angular models. J. Appl. Meteor., 39, 2278-2291, https://doi.org/10.1175/1520-0450(2001)040<2278: EOSDRF $>2.0 . \mathrm{CO} ; 2$. 
Magalhães, N., H. Evangelista, T. Condom, A. Rabatel, and P. Ginot, 2019: Amazonian biomass burning enhances tropical Andean glaciers melting. Sci. Rep., 9, 16914, https://doi.org/ 10.1038/s41598-019-53284-1.

Magrin, G. O., J. A. Marengo, J.-P. Boulanger, M. S. Buckeridge, E. Castellanos, G. Poveda, F. R. Scarano, and S. Vicuña, 2014: Central and South America. Climate Change 2014: Impacts, Adaptation, and Vulnerability, Part B: Regional Aspects, V. R. Barros et al., Eds., Cambridge University Press, 1499-1566, https://www.ipcc.ch/site/assets/uploads/2018/02/WGIIAR5Chap27_FINAL.pdf.

Molod, A., L. Takacs, M. Suarez, and J. Bacmeister, 2015: Development of the GEOS-5 atmospheric general circulation model: Evolution from MERRA to MERRA2. Geosci. Model Dev., 8, 1339-1356, https://doi.org/10.5194/gmd-8-1339-2015.

Morgan, W. T., E. Darbyshire, D. V. Spracklen, P. Artaxo, and H. Coe, 2019: Non-deforestation drivers of fires are increasingly important sources of aerosol and carbon dioxide emissions across Amazonia. Sci. Rep., 9, 16975, https://doi.org/10.1038/s41598-019-53112-6.

NOAA, 2007: El Niño/Southern Oscillation-Annual 2007. NCEI, accessed 5 May 2020, www.ncdc.noaa.gov/sotc/enso/200713.

Palácios, R. D., and Coauthors, 2020: Long term analysis of optical and radiative properties of aerosols in the Amazon Basin. Aerosol Air Qual. Res., 20, 139-154, https://doi.org/10.4209/ aaqr.2019.04.0189.

Pasquali, M., 2020: Deforestation area in the Brazilian Amazon. Statista, accessed 14 August 2020, www.statista.com/statistics/ 940696/.

Penner, J. E., R. E. Dickinson, and C. A. O'Neill, 1992: Effects of aerosols from biomass burning on the global radiation budget. Science, 256, 1432-1433, https://doi.org/10.1126/science.256.5062.1432.

Potter, C., V. Brooks-Genovese, S. Klooster, and A. Torregrosa, 2002: Biomass burning emissions of reactive gases estimated from satellite data analysis and ecosystem modeling for the Brazilian Amazon region. J. Geophys. Res., 107, 8056, https:// doi.org/10.1029/2000JD000250.

Procopio, A. S., P. Artaxo, Y. J. Kaufman, L. A. Remer, J. S. Schafer, and B. N. Holben, 2004: Multiyear analysis of Amazonian biomass burning smoke radiative forcing of climate. Geophys. Res. Lett., 31, L03108, https://doi.org/10.1029/2003GL018646.
Randles, C. A., A. M. Silva, V. Buchard, P. R. Colarco, A. Darmenov, and R. Govindaraju, 2017: The MERRA-2 aerosol reanalysis, 1980 onward. Part I: System description and data assimilation evaluation. J. Climate, 30, 6823-6850, https://doi.org/10.1175/JCLI-D-16-0609.1.

Ross, J. L., P. V. Hobbs, and B. Holben, 1998: Radiative characteristics of regional hazes dominated by smoke from biomass burning in Brazil: Closure tests and direct radiative forcing. J. Geophys. Res., 103, 31 925-31 941, https://doi.org/10.1029/ 97JD03677.

Stein, A. F., R. R. Draxler, G. D. Rolph, B. J. B. Stunder, M. D. Cohen, and F. Ngan, 2015: NOAA's HYSPLIT atmospheric transport and dispersion modeling system. Bull. Amer. Meteor. Soc., 96, 2059-2077, https://doi.org/10.1175/BAMS-D14-00110.1.

Thonat, T., C. Crevoisier, N. A. Scott, A. Chédin, T. Schuck, R. Armante, and L. Crépeau, 2012: Retrieval of tropospheric CO column from hyperspectral infrared sounders-Application to four years of Aqua/AIRS and MetOp-A/IASI. Atmos. Meas. Tech., 5, 2413-2429, https://doi.org/10.5194/amt-5-2413-2012.

Thornhill, G., C. Ryder, E. Highwood, L. Shaffrey, and B. Johnson, 2018: The effect of South American biomass burning aerosol emissions on the regional climate. Atmos. Chem. Phys., 18, 5321-5342, https://doi.org/10.5194/acp-18-5321-2018.

Winker, D. M., W. M. Hunt, and M. J. McGill, 2007: Initial performance assessment of CALIOP. Geophys. Res. Lett., 34, L19803, https://doi.org/10.1029/2007GL030135.

Worden, H. M., M. N. Deeter, D. P. Edwards, J. C. Gille, J. R. Drummond, and P. Nedelec, 2010: Observations of nearsurface carbon monoxide from space using MOPITT multispectral retrievals. J. Geophys. Res., 115, D18314, https:// doi.org/10.1029/2010JD014242.

Yang, Y., and Coauthors, 2018: Post-drought decline of the Amazon carbon sink. Nat. Commun., 9, 3172, https://doi.org/ 10.1038/s41467-018-05668-6.

Yurganov, L. N., W. W. McMillan, A. V. Dzhola, E. I. Grechko, N. B. Jones, and G. R. van der Werf, 2008: Global AIRS and MOPITT CO measurements: Validation, comparison, and links to biomass burning variations and carbon cycle. J. Geophys. Res., 113, D09301, https://doi.org/10.1029/2007JD009229. 